\title{
National Security and Human Rights in International Law
}

\author{
P. Sean Morris \\ https://doi.org/10.21827/GroJIL.8.1.123-149
}

\section{Keywords \\ HUMAN RIGHTS; NATIONAL SECURITY; CONFLICT; STATIST LOGIC}

\begin{abstract}
The post war-on-terror era has witnessed several developments in international law, including the nature and function of national security. This article establishes a link between national security and human rights by looking at some practical implications from a State policy perspective and theoretical views. Any discussion on the two distinct areas of 'national security' and 'human rights' are, of course, not equal. However, the discussions in this article relate to how international law interacts with national security over human rights given that national security relates to a State's domestic affairs but with implications for the international legal system. Thus, through theory and practice, this article demonstrates that national security and human rights are unstable. This article addresses the question of whether national security and human rights obligations are in conflict or whether international law has been over-responsive or under-responsive to either human rights or national security concerns.
\end{abstract}

\section{Introduction}

There are two uncontested doctrines in international law concerning States - sovereignty as a form of right, and the right to the national security of the State. The former is a well-known doctrine in international law, ${ }^{1}$ whilst the latter is a broad standard and usually contains, inter alia, the right to declare war, the right of a State to defend itself, and the right to public order. ${ }^{2}$ For a State to exist, it must display these two characteristics as a genuine political entity 'in order to procure their mutual welfare and security, ${ }^{3}$ or promote its 'internal security and national defense', ${ }^{4}$ and therefore claim its place among nations as a sovereign State. This means that security is at the heart of the very existence of a State and, as such,

\footnotetext{
P Sean Morris, LLD, Research Scholar, Faculty of Law, University of Helsinki. This paper was written in the fall of 2016 and minor changes and updates have been carried out to reflect developments in the law. However, the argument, style and substance of the original paper has been retained.

1 See generally, J Bartelson, A Genealogy of Sovereignty (CUP 1995).

2 See BVA Rolling, 'The Concept of Security and the Function of National Armed Power' in A Cassese (ed), The Current Legal Regulation of the Use of Force (Nijhoff 1986) 283-322; J Robb, Brave New War: The Next Stage of Terrorism and the End of Globalization (John Wiley \& Sons 2007); White House, 'The National Security Strategy of the United States of America' (17 September 2002); Michael Supperston, Brownlie's Law of Public Order and National Security ( $2^{\text {nd }}$ ed, Butterworths 1981); Antonela Sofinet, 'Defining Doctrinal Principles in the Area of Public Order and National Security' (2015) 2015 European Journal of Public Order and National Security 33; Matej Avbelj, 'Security and the Transformation of the EU Public Order' (2013) 14 German Law Journal 2057.

3 James Crawford, The Creation of States in International Law (OUP 2007) 7, citing Vattel.

4 William Thomas Worster, 'Law, Politics, and the Conception of the State in State Recognition Theory' (2009) 27 Boston University International Law Journal 115, citing Robert Delahunty \& John Yoo, 'Statehood and the Third Geneva Convention' (2005) 46 Virginia Journal of International Law 131; HB Jacobini, 'The Right of State Existence in International Law' (1950) 30 Southwestern Social Science Quarterly 277.
} 
security, for modern purposes, includes the vague and broad concept of national security. ${ }^{5}$ Under this broad concept, in which the ordre public of a sovereign State's internal affairs seeks shelter from the realms of evil (aggression and subversion), States are the supreme law-makers and power brokers on the international legal plane.

As there are competing aspects of security in legal and policy discourse, this paper deals with national security, as determined by a State, particularly at the domestic level. Hence, it is a sort of State security that focuses on the safety of the nation State, as opposed to collective security or human security. For instance, a government may deploy troops on home soil in order to tackle crime or illegal immigration for national security reasons. ${ }^{6}$ In other instances, the where and when of national security being invoked can be on very vague and evasive grounds. ${ }^{7}$ The conception of national security in this paper plays on the Cold War realist conception, which encompasses the self-interest of the nation State. ${ }^{8}$

All sovereign States have different means at their disposal to safeguard their national security interests. Since the war on terror, a number of States have developed 'national security strategies' that set out the policy, legal and other methods to safeguard their national security. ${ }^{9}$ Furthermore, due to the vagueness of the concept of national security, States can justify any action within that paradigm. ${ }^{10}$ In some States, the idea of national security will often escape the judicial community due to the integration of intelligence strategies, the ordre public or counter-terrorism. When judicial bodies do consider national security, the issues often remain sensitive and / or confidential. In some jurisdictions, questions of national security are also linked to criminal law and this creates a blur between traditional civilian courts and those that are designated as special tribunals for national security matters.

Moreover, due to the convergence of national security with criminal law in some States, it is increasingly difficult to separate the two when both are at play, if defendants have recourse to only one legal system. Take, for example, $A v$ Secretary of State for the Home Department, ${ }^{11}$ a case where foreign prisoners challenged the UK's Anti-Terrorism Act $2001^{12}$ as unlawful, at least in relation to international law such as the European

5 For example, the 1995 Hungarian Act on the National Security Services (Act CXXV of 1995), provides in Section 3 that national security also covers the protection of national sovereignty and the constitutional order; For a concrete discussion on the notion of a 'national security State' see Amichai Cohen and Stuart Cohen, Israel's National Security Law: Political Dynamics and Historical Development (Routledge 2012).

6 See Michael Head and Scott Mann, Domestic Deployment of the Armed Forces: Military Powers, Law and Human Rights (Ashgate 2009) 8; see generally, Scott Sheeran, 'Reconceptualizing States of Emergency Under International Human Rights Law: Theory, Legal Doctrine, and Politics' (2013) 34 Michigan Journal of International Law 491; Douglas Lee Donoho, 'The Role of Human Rights in Global Security Issues: A Normative and Institutional Critique' (1993) 14 Michigan Journal of International Law 827.

7 For example, under the British Civil Contingencies Act (2004), which empowers the government to deploy troops in case of certain 'emergencies'.

8 Nigel White, 'Security Agendas and International Law: The Case of New Technologies' in Mary Footer, Julia Schmidt, Nigel White and Lydia Davies-Bright (eds), Security and International Law (Oxford: Hart Publishing 2016) 6; David Forsythe, Human Rights in International Relations ( $3^{\text {rd }}$ edn, CUP 2012) 3, noting that 'realism is a synonym for attention to State interests - foremost among which is security.'; Rhonda Callway and Elizabeth Matthews, Strategic US Foreign Assistance: the Battle between Human Rights and National Security (Routledge 2008); Jiri Valenta and William Potter, Soviet Decision-Making for National Security (London: George Allen \& Unwin 1984); see also Piet Hein van Kempen, 'Four Concepts of Security - A Human Rights Perspective' (2013) 13 Human Rights Review 1.

9 See, for example, US National Security Strategy (n 2).

10 Hitoshi Nasu, 'State Secrets and National Security' (2015) 64 International and Comparative Law Quarterly 365.

11 A and Ors $v$ Secretary of State for the Home Department (2004) UKHL 56.

12 Anti-Terrorism, Crime and Security Act (2001). 
Convention on Human Rights (ECHR) ${ }^{13}$ since they were being indefinitely held without trial. In that case, the then House of Lords agreed with the foreign defendants but the significance of the case relates to the fact that the Anti-Terrorism Act 2001 applied only to foreign defendants and UK defendants had recourse to domestic criminal law.

In other areas, most EU States have a policy of rehabilitation regarding criminal sanctions for citizens and aliens alike, most notably in the Nordic countries, whilst the US and the UK concentrate on maximum incarcerations. ${ }^{14}$ This observation is significant for two reasons. The first is that domestic criminal law and policy affects how the courts in those jurisdictions approach and view international law and aliens in their criminal justice system. This was most evident in cases such as Hamdan $v$ Rumsfeld and $A v$ Home Department, where two distinctive approaches were taken. In Hamdan $v$ Rumsfeld, alien criminals are excluded from the scope of international law and human rights in the American context, ${ }^{15}$ and, in the case of the UK, the reliance on human rights by alien criminals and terror suspects affects effective criminal justice. ${ }^{16}$

Under these scenarios, in jurisdictions such as the US, where alien terror suspects pose a threat to national security, it is the applicable domestic law, such as the Military Order of 2001, that is relevant. ${ }^{17}$ The Military Order of 2001 circumvents the need to apply international law to alien terror suspects. As such, the US effectively and legally denies alien criminals and terror suspects human rights claims or the possibility of such claims deserving credence. ${ }^{18}$ In the words of one commentator: 'American courts are giving short shrift by and large to human rights norms when they come into conflict with national security. ${ }^{, 19}$ Thus, for alien criminals or terror suspects facing the criminal justice system of the USA, raising human rights arguments as a defence is not straightforward.

Firstly, the rights of aliens are, for the most part, seen as part of the broader scope of 'human freedom'. ${ }^{20}$ Moreover, human rights in the US context are best construed as constitutional rights. ${ }^{21}$ In this regard, for aliens to construct their arguments in terms of what are understood as human rights in Europe and other parts of the world would be seen by the US courts as 'fads or fashions', ${ }^{22}$ or foreign moods. However, this does not mean that that US courts outright reject human rights as understood internationally. On the contrary, the US has long been the champion of a number of international human rights instruments that have had a profound effect in Europe and other parts of the world.

13 European Convention on Human Rights 1950.

14 For similar views, see John Pratt and Anna Eriksson, Contrasts in Punishment: An Explanation of Anglophone Excess and Nordic Exceptionalism (Routledge 2013).

15 See, for example, Hamdam v Rumsfeld, 548 US 557 (2006) and Av Home Department [2005] UKHL 71.

16 The UK has often objected to parts of the ECHR and rulings from the ECtHR pertaining to alien criminals or voting rights for prisoners: see, for example, Hirst $v$ UK (No.2) App No 74025/01 (ECtHR, 6 October 2005).

17 Military Order of 13 November 2001: Detention, Treatment, and Trial of Certain Non-Citizens in the War Against Terrorism, 3 CFR 919 (2002).

18 P Ward, 'National Security versus Human Rights: An Even Playing Field' (2010) 104 ASIL Proceedings $458,459$.

19 ibid 461.

20 Lawrence $v$ Texas, 539 US 588 (2003); ibid.

21 For a discussion on the morality of human rights in America, see Michael Perry, Human Rights in the Constitutional Law of the United States (CUP 2013); For an assessment of human rights in general, see Mark Goodale (ed), Human Rights at the Crossroads (OUP 2013); For legal and other insights into questions of legitimacy and human rights, see Andreas Follesdal, Johan Karlsson Schaffer and Geir Ulfstein, The Legitimacy of International Human Rights regime: Legal, Political and Philosophical Perspectives (CUP 2013).

22 Lawrence (n 20). 
However, it is important to note that the line between national security and human rights has become such a dangerous zone of legal landmines that it is possible to use certain instruments in some domestic settings (such as the US Alien Tort Act) ${ }^{23}$ to detect and raise human rights claims whilst, on the other hand, it is possible to directly encounter other instruments (such as the US War Crimes Act) that can strike human rights claims hard. The primary reason for this is because, under certain circumstances, human rights claims are in direct conflict with national security, meaning there is a dichotomy to balance between these two interests. ${ }^{24} \mathrm{I}$ do not pretend that I can find such balance in this paper. Rather, I am approaching some specific issues regarding human rights and national security in order to determine the significance of other relevant legal regimes, particularly international law.

\section{Conflicts and the Essence of National Security}

It is safe to argue that conflicts highlight the importance of national security. The form that such conflict may take is another matter. ${ }^{25}$ Furthermore, the rise in armed conflicts can also be attributed to new actors which, some scholars have argued, have their sole motive as the erosion of the State. ${ }^{26}$ Interestingly, the modern trend in armed conflicts seems to either rise or remain unsettled through attempts at peaceful negotiation. ${ }^{27}$

Regional skirmishes involving the internal security of minor or failed States may not pose a security threat to powerful States, unless the minor State has weapons of mass destruction and there is a possibility of such weapons falling into the wrong hands. On the other hand, a civil war or other internal conflict in a powerful State such as Russia may have consequences beyond the Russian border and may even affect the national security of the US or the ordre public of the European Union. In comparison, conflicts in African failed States do not necessarily affect the national security of the European Union or the US, but only the national security of the States directly involved. The counterargument is that conflicts in failed States in Africa affect the national security of the US or the EU through immigration policies, where generous refugee rules can result in loopholes allowing those with terrorist motives to find sanctuary in Western States.

23 Alien Tort Act 28 US Code $\S 1350$.

24 See, for example, Liora Lazarus and Benjamin Goold, 'Security and Human Rights: The Search for a Language of Reconciliation' in Benjamin Goold and Liora Lazarus (eds), Security and Human Rights (Hart 2007); see also, J Petman, 'Security and Rights in the War on Terror: On the Constitutive Insecurity of Rules' in Massimo Fichera and Jens Kremer (eds), Law and Security in Europe: Reconsidering the Security Constitution (Intersentia 2013) 129-177, at 151-160; see generally Harold Koh, The National Security Constitution: Sharing Power After the Iran-Contra Affair (Yale 1990).

25

For example, in the late 1990s a number of conflicts around the world that affected the national security of the States involved with spill-over effects on the international arena were raging in areas such as Kosovo, Tajikistan in the Former Soviet Union, Northern Ireland, Kashmir on the Indian Sub-Continent and Rwanda, among many other regions. Most of these were deemed armed conflicts where the use of force was an essential part of the 'defence' and thus involved customary rules of international law, thereby involving international security in the traditional sense, and not 'national security' as this paper advances; see, for example, SIPRI, Armaments, Disarmament and International Security, Yearbook 1999 (OUP 1999); see generally Ustina Dolgopol and Judith Gardam (eds), The Challenge of Conflict: International Law Responds (Martinus Nijhoff Publishers 2006).

26 See Arnaud Blin, 'Armed Groups and Intra-State Conflicts: The Dawn of a New Era?' (2011) 93 International Review of the Red Cross 287, 296 (arguing that human right, in principle, has a long history in armed conflicts).

27 See, for example, SIPRI, Yearbook 2014: Armaments, Disarmament and International Security (OUP 2014); Sean Morris, 'Book Review: Stockholm International Peace Research Institute, SIPRI Yearbook 2014: Armaments, Disarmament and International Security' (2016) 14 Political Studies Review 440, discussing the amount of conflicts settled through negotiation in 2013. 
During the various uprisings in the Middle East, conveniently named the Arab Spring, such civil unrests in principle only exacerbated some of the underlying conflicts that posed a threat to the sovereignty of those States. Some of the underlying problems were drawn along ethnic lines, or concerned political opposition, and manifested in various revolutions starting in 2011. This is most notable in Syria, where a civil war threatened the unity of the State and included external States as proxies. That civil war has drawn in the lone superpower, the United States, partly for national security reasons and partly due to the involvement of the erstwhile superpower, the Russian Federation, for reasons of pride and to reassert its power.

Due to the number of refugees that the prolonged Syrian civil war has generated and their claims for refugee status in Europe, there is always the concern that some refugees may pose a national security risk to EU Member States. ${ }^{28}$ The EU has nevertheless dealt with refugee claims within its obligations under international law, ${ }^{29}$ but often finds itself between heaven and hell. This is because, on the one hand, from a strategic economic point of view, the surge of refugees in Europe is a boon to the labour force and yet, at the same time, these countries have to deal with the grave threat to their national security that some of these refugees have brought to their shores. In the strictest of legal senses, these arguments are better considered in light of the principle of non-refoulment. ${ }^{30}$ However, an extensive analysis thereof is not the object of this article. ${ }^{31}$

The issue of national security and human rights is also a further concern regarding the new type of conflict that occurs in cyberspace because of internet communication technologies. Cyber conflicts, ${ }^{32}$ whether initiated through distributed denial of service

28 See also Sarah Singer, Terrorism and Exclusion from Refugee Status in the UK: Asylum Seekers Suspected of Serious Criminality (Brill 2015); For similar discussions in relation to the US see Peter Margulies, 'Uncertain Arrivals: Immigration, Terror, and Democracy after September 11' (2002) 2002 Utah Law Review 481; For some other general commentaries see J Huysmans, 'Migrants as a Security Problem: Dangers of "Secrutizing" Societal Issues' in R Miles and D Thranhardt (eds), Migration and European Integration: the Dynamics of Inclusion and Exclusion (Pinter Publishers 1995); SW Choi and I Salehyan, 'No Good Deed Goes Unpunished: Refugees, Humanitarian Aid and Terrorism' (2013) 30 Conflict Management and Peace Science 53; A Sivanandan, 'Race, Terror and Civil Society' (2006) 47 Race and Class 1; J Hatch, 'Requiring a Nexus to National Security: Immigration, "Terrorist Activities," and Statutory Reform' (2014) BYU Law Review 697.

29 See James Hathaway, The Rights of Refugees under International Law (CUP 2005).

30 See, for example, Veronika Flegar, 'Vulnerability and the Principle of Non-Refoulement in the European Court of Human Rights: Towards an Increased Scope of Protection for Persons Fleeing from Extreme Poverty?' (2016) 8 Contemporary Readings in Law and Social Justice 148; Christopher Michaelson, 'The Renaissance of Non-Refoulment: The Othman (Abu Qatada) Decision of the European Court of Human Rights' (2012) 61 International and Comparative Law Quarterly 759.

31 I must point out that the ECtHR addressed the principle of non-refoulment in a number of cases, such as Soering $v$ United Kingdom App No 14038/88 (ECtHR, 7 July 1989) where it confirmed state obligations pertaining to extradition; furthermore, the non-refoulment principle is included in a number of treaties, and in that regard, the Soering Court argued that provisions such as Article 3 in the ECHR contains 'inherent' obligations of non-refoulment (para 88); In another case, Chahal v UK App No 22414/93 (ECtHR, 15 November 1996) para 80, the Court affirmed: 'whenever substantial grounds have been shown for believing that an individual would face a real risk of being subjected to treatment contrary to Article 3 (art. 3) if removed to another State, the responsibility of the Contracting State to safeguard him or her against such treatment is engaged in the event of expulsion....).'.

32 For some general discussion see Richard Clarke, 'Threats to U.S. National Security: Proposed Partnership Initiatives Towards Preventing Terrorist Attacks' (2000) 12 DePaul Business Law Journal 33; Nathan Sales, 'Regulating Cyber-Security' (2013) 107 Northwestern University Law Review 1503; Yoram Dinstein, 'The Principle of Distinction and Cyber War in International Armed Conflicts' (2012) 17 Journal of Conflict and Security Law 261; Annegret Bender and Andrew Porter, 'European Cyber 
(DDoS) attacks such as on Estonia in 2007, or through more modern and sophisticated methods, generally constitute a form of 'attack' for the purposes of the law of armed conflict. ${ }^{33}$ Therefore, under such circumstances, human rights implications also emerge even if such 'attacks' occur in cyberspace. ${ }^{34}$ For instance, the right to privacy as enunciated under Article 17 of the International Covenant on Civil and Political Rights (ICCPR) forms a direct correlation to cyber conflicts, as the activities of a belligerent cyber entity or individual can harm the targeted person and therefore breach his rights under international law. In the Delfi Case, the ECtHR found that the equivalent of Article 17 ICCPR was breached when an Estonian information internet site caused harm to a ferry operator. ${ }^{35}$ These examples show that cyber conflict is a form of silent conflict, as I posited elsewhere, ${ }^{36}$ that outdistanced Cold War era conflicts, and reasserted espionage and destruction in a contemporary sense with devastating effects. The international initiatives to respond to cyber conflict, such as the Tallinn Manual, are admirable, ${ }^{37}$ although such efforts to some extent are in vain when they develop principally as adversarial tools in organisations such as NATO.

Regardless of where a conflict occurs, whether in cyberspace or on the territory of sovereign States, States are prepared to take actions to defend their territory or territorial information infrastructures. States are required to observe international human rights law when facing such conflicts. However, given that national security concerns often drive States to 'protect' themselves in event of an 'attack', it is still unclear where human rights laws are applicable in the event of an 'attack' and national security justifications are often invoked to suspend human rights laws. Thus, armed conflicts still require peaceful settlement, and the settlement of these conflicts would be of mutual benefit to the international community, in particular if the States where the conflicts are taking place are considered as sources of a national security threat to other States.

From a theoretical point of view, one study identifies four concepts of security that are inextricably linked to human rights. According to van Kempen, 'international security through human rights protection by States', 38 'negative individual security against the State', ${ }^{39}$ 'security as justification to limit human rights' ${ }^{40}$ and 'positive State obligation to offer security to individuals' ${ }^{\prime 4}$ are all part of a complex system that links human rights to security. Yet, despite this positive relation between human and security norms, van Kempen concludes that 'international human rights law offers neither an unequivocal nor a clear perspective on security. ${ }^{42}$ This finding is important because the international legal

Security within a Global Multistakeholder Structure' (2013) 18 European Foreign Affairs Review 155; Titiriga Remus, 'Cyber-Attacks and International Law of Armed Conflicts: A Jus Ad Bellum Perspective' (2013) 8 Journal of International Commercial Law and Technology 179.

See also Dinstein (n 32) 264.

34 See Herbert Lin, 'Cyber Conflict and International Humanitarian Law' (2012) 94 International Review of the Red Cross 515.

35 Delfi As v Estonia App No 64569/09 (ECtHR, 16 June 2015).

36 See P Sean Morris, 'iSpy: International Silent Conflicts, Cyber Warfare and Developments in International Diplomatic Law' (Working Paper, 2012) (on file with author).

37 See, for example, Lianne JM Boer, 'Restating the Las as it Is: On the Tallinn Manual and the Use of Force in Cyberspace' (2013) 5 Amsterdam Law Forum 4.

38 van Kempen (n 8) 3.

39 ibid 9.

40 ibid 13.

41 ibid 16.

42 van Kempen (n 8). 
system, including international human rights law, has long championed human rights as the most privileged and safe concept for the vulnerable and stateless in international law.

Yet, at the same time, international norms reveal that the international human rights system of rules depends on how they interact with the national rules of States, and whether those human rights rules contravene or interfere with the administration of justice and national security. ${ }^{43}$ Another argument that van Kempen develops is the idea of peace as a result of conflict, which involves human rights peace theory, whereby on some occasions 'security between States has increasingly come to depend on security within those States. ${ }^{44}$ For the purposes of this section of this paper, this observation is actually part of the essence of conflict and national security. In other words, and as van Kempen also posits, due to the complexity of internal conflict, human rights breaches (at the national level) are often the root cause of, or can directly trigger, conflict. ${ }^{45}$ Thus, if the human rights (or constitutional or political rights at the national level) of citizens are not upheld by the State, such States can plunge into internal conflict as a result of those breaches.

In a number of States where internal conflicts have taken place, or are still ongoing, it is easily deducible that such conflicts occur because of repression by a regime or other systematic deprivation of human rights. The response at the international level is a call for the respect of international human rights law and similar obligations in the international legal system. The next section addresses such obligations.

\section{International Human Rights Obligations: Link to National Security}

The international human rights system is a legal minefield, dotted with various legal instruments and regulations which, in one sense, provide the possibility to incorporate a vast array of concepts into the human rights narrative. ${ }^{46}$ Thus, linking international human rights to national security is not far-fetched. Van Kempen found that there is no real linkage between international human rights and security, ${ }^{47}$ but one can question whether this is really the case and what the exact nature of international human rights obligations is in relation to national security. There are no answers to these questions, and this section merely attempts to extrapolate upon some of these intricacies.

The current international legal regime on human rights is a consequence of the Second World War. Thus, the Charter of the United Nations (UN Charter) ${ }^{48}$ the Universal Declaration of Human Rights (UDHR) ${ }^{49}$ the International Covenant on Civil and Political Rights (ICCPR $)^{50}$ and the International Covenant on Economic, Social, and Cultural

43 ibid 22 noting: 'in order to be able to operate an adequate criminal justice system and other security measures, authorities must - under specific conditions and if necessary - have the possibility to infringe some human rights.'.

ibid 5; see also, Gerd Oberleitner, Human Rights in Armed Conflict: Law, Practice and Policy (CUP 2015).

46 Some have proposed that the relationship between the media and the law has a beneficial impact on society, see Daniel Joyce, 'Human Rights and the Mediatization of International Law' (2010) 23 Leiden Journal of International Law 507.

47 van Kempen (n 8).

48 Charter of the United Nations (adopted 26 June 1945, entered into force 24 October 1945) 1 UNTS XVI; for commentary, see Alex Petrenko, 'The Human Rights Provisions of the United Nations Charter' (1979) 9 Manitoba Law Journal 53; Bardo Fassbender, The United Nations Charter as the Constitution of the International Community (Martinus Nijhoff 2009).

49 UNGA Res 217A (III) (10 December 1948) UN Doc A/810.

50 International Covenant on Civil and Political Rights (adopted 16 December 1966, entered into force 23 March 1976) 999 UNTS 171. 
Rights (ICESR) ${ }^{51}$ were designed to provide the necessary legal avenues for the protection of Europeans who endured much suffering during the conflict. ${ }^{52}$

The 1945 UN Charter was the first international legal instrument to promote modern international human rights. From the perspective of the UN Charter, fundamental rights and freedoms were designed as part of the grand bargain that resulted in the establishment of the UN and brought in the 'new international law of human rights.' ${ }^{3}$ However, it is the UDHR that is the actual blueprint of the modern international human rights legal system and some argue that even the UDHR has a long and complicated history, going as far back as the American and French Revolutions. ${ }^{54}$

Outside the debate on the actual origins of the UDHR, it is accepted as one the current normative pillars of international human rights law and, as such, there are linkages between that document and national security as I have broadly conceived it to be in this paper. From this argument, it follows that the intersection of human rights with other regimes involves some form of State practice. Hence, a State may have special interests in national security as a regime and create customary obligations. State practice is the mechanical device that gives rise to customary international law and, therefore, acts or statements (such as those on national security strategies) which allows for inferences to be made regarding State belief on international law. ${ }^{55}$ Thus, the interaction of national security strategies with human rights lies in the fact that national security strategies are a form of State practice and therefore part of the process that generates customary international law.

Of course, one could interpret references in the preamble of the UDHR as references to security, such as 'recourse, as a last resort, to rebellion against tyranny and oppression. ${ }^{56}$ However, these can also be viewed as a description of the internal chaos of States, whereby State administrators (dictators/leaders) opposed their own people, and hence not a national security issue in the traditional sense. The UDHR was adopted in 1948 when the state of affairs was not exactly rosy. The war was still fresh in the memory of many people and the victors were concerned with how human rights violations in States

51 International Covenant on Economic, Social and Cultural Rights (adopted 16 December 1966, entered into force 3 January 1976) 993 UNTS 3; Although the ICESCR is considered part of the family of human rights treaties, it is more designed as a human security charter, addressing the economic and social aspects of human security. Furthermore, the ICESCR is, in some respects, a protégé of its much older sibling, the European Social Charter of 1961.

52 See, for example, Pamela Ballinger, 'Entangled or "Excluded" Histories, Displacement, National Refugees, and Repatriation after the Second World War' (2012) 25 Journal of Refugee Studies 366; PR Ghandhi, 'The Universal Declaration of Human Rights at Fifty Years: Its Origins, Significance and Impact' (1998) 41 German Yearbook of International Law 206; Dennis Gallagher, 'The Evolution of the International Refugee System' (1989) 23 International Migration Review 579; James Carlin, 'Significant Refugee Crises Since World War II and the Response of the International Community' (1982) 3 Michigan Journal of International Law 3, 6 (noting that 'the focus of international attention on the refugee problem in the early and mid-1950s remained in Europe').

53 Louis Henkin, The Rights of Man Today (Westview Press 1978) 94; See also, Charter of the United Nations (adopted 26 June 1945, entered into force 24 October 1945) 1 UNTS XVI, Preamble.

54 On this point, see generally Pamela Slotte and Miia Marika Halme-Tuomisaari, Revisiting the Origins of Human Rights (CUP 2015); see also Christian Reus-Smit, Individual Rights and the Making of the International System (CUP 2013).

55 Michael Akehurst, 'Custom as a Source of International Law' (1975) 47 BYBIL 1, 10.

56 UDHR (n 49) $3^{\text {rd }}$ Preamble. 
could destabilise those States' national security and the effect of such destabilisation on the wider international community. ${ }^{57}$

Conscious of this, the UDHR proclaims from the outset: 'whereas disregard and contempt for human rights have resulted in barbarous acts which have outraged the conscience of mankind' ${ }^{58}$ as a direct reference to human rights violations that were well within the national laws of States. Nazi Germany was perhaps the ideal example of this scenario, whereby the State trampled on the rights of its own citizens (mostly in relation to Jews and other minority groups). ${ }^{59}$ The problem was that States could not intervene per se in the affairs of another State.

The UDHR itself has other examples that can be seen as references to national security. For instance, in Article 3, a clear link to national security is established. Article 3 provides that 'everyone has the right to life, liberty and security of person. ${ }^{160}$ The latter part of Article 3 confirms that 'security of person' refers to 'the right of being protected against certain intensive interferences from the State. ${ }^{61}$ In other words, Article 3 of the UDHR is concerned with protecting the rights of individuals from State sponsored national security objectives that affect the human rights of the individual.

Taken literally, what this means is that States ought to ensure that, as a part of their internal national security policy, the security of their citizens is well protected when the broad and vague policy objectives of national security are implemented. The alternative would be that internal chaos would prevail and therefore destabilise national security. Article 3 should also be seen in relation to Article 5 and Article 9 of the UDHR, which cover, in Article 5, torture and inhuman and degrading treatment or punishment and, in Article 9, arbitrary arrest or detention. Together, these provisions of the UDHR create a triad of links between national security and human rights which are, in a sense, the very same aspects in contemporary human rights discourse that provoke questions on national security.

Perhaps the strongest linkage the UDHR creates between human rights and national security is that, as the grand dame of the international human rights system, most other regional and national human rights rules adopted or used the model of the UDHR. ${ }^{62}$

57 The actual origins of modern human rights law must always be understood as European in that they were created to deal with tragic events in Europe and out of concern for the European people, to stand against oppression, barbarism and political oppression. Nevertheless, as an instrument that applies to all peoples of the world, over the years various States have made use of the language and aspirations of the UDHR within the broader framework of international law, especially regarding the issue of rights. For philosophical observation on rights see, for example, Alison Kesby, The Right to Have Rights: Citizenship, Humanity, and International Law (OUP 2012); Jochen von Bernstorff, 'The Changing Fortunes of the Universal Declaration of Human Rights: Genesis and Symbolic Dimensions of the Turn to Rights in International Law' (2008) 19 European Journal of International Law 903.

58 UDHR (n 49) $2^{\text {nd }}$ Preamble.

59 See, however, Jan-Olof Sundell, 'The Destruction of Democracy and Civil Rights in Germany 1933' in Peter Wahlgren (ed), Human Rights: Limitations and Proliferation (Stockholm 2010) 243-268.

60 UDHR (n 49) Article 3.

61 See L Rehof, 'Article 3' in Asbjorn Eide et al (eds), The Universal Declaration of Human Rights: A Commentary (Scandinavian University Press 1992) 73.

62 See, for example, Convention for the Protection of Human Rights and Fundamental Freedoms (European Convention on Human Rights, as amended) (ECHR); American Convention on Human Rights (ACHR) (adopted 22 November 1969, entered into force 18 July 1978) 1144 UNTS 123; African Charter on Human and Peoples' Rights (adopted 27 June 1981, entered into force 21 October 1986) (1982) 21 ILM 58 (African Charter); the court systems for these regional human rights treaties interpret and provide guidance; the ECHR has a court system that is able to interpret and provide guidance on the fundamental freedoms that are provided for in the ECHR, Article 8 in particular has a direct connection 
The European Convention on Human Rights and Fundamental Freedoms ${ }^{63}$ and the UK Human Rights Act $1998^{64}$ are prominent examples, the latter being an instrument that legally binds a State to international treaties on human rights that follow the aspirations set out in the UDHR.

The ICCPR is one of the major binding international legal instruments on human rights which is, in one sense, a direct descendant of the UDHR. Echoing Article 12 of the UDHR, the ICCPR provides, in Article 17, for the protection of privacy, family, home and correspondence ${ }^{65}$ However, Article 12 of the ICCPR explicitly mentions national security as a subject matter of human rights. According to this provision, individual freedoms should not be curtailed unless a national security measure to protect them is required: '[human] rights shall not be subject to any restrictions except those which are provided by law, are necessary to protect national security, public order (ordre public).... ${ }^{66}$ Similarly, Articles 13, 14, 19, 21, and 22 reinforce exceptions to human rights on the ground of national security. ${ }^{67}$

The wording used in Article 12 regarding the permissible purposes for interference in human rights protection connotes two levels of exception: a low-level exception based on public order and a high-level exception based on national security. Thus, the low-level exception in the ICCPR conceivably involves internal threats to the State, and/or threats posed by individuals. In such instances, the freedoms of individuals may be suspended or denied on certain grounds. An example of a low-level exception could the posting of an army in the internal borders of a State to help mitigate threats such as illegal immigration. However, one can argue that it is up to the domestic criminal justice system to properly respond to the low-level exception that Article 12 of the ICCPR advocates.

On the other hand, the high-level exception that I interpret Article 12 of the ICPR as advocating would perhaps involve external threats to the State, such as war, military threats ${ }^{68}$ or even cyber-attacks, and therefore would pose a national security problem. In

to national security concerns; see cases such as Rotaru v Romania App no 28341/95 (ECtHR, 4 May 2000) ECHR 192.

63

ECHR (n 62).

64 Human Rights Act (1998).

65 The ICCPR in general expands the rights that are in Articles 1-21 of the UDHR. Some ICCPR cases include: Celepli v Sweden, Communication No.456/1991, UN Doc CCPR/C/51/D/456/1991 (1994); Karker v France, Communication No.833/1998, UN Doc CCPR/C/70/D/833/1998 (2000).

66 ICCPR (n 26) article 12(3); in general, Article 12 of the ICCPR refers to freedom of movement, and Article 12(3) only notes that limitations to this right may be put in place; in the General Comments provided by the Human Rights Committee on the ICCPR, it notes in paragraph 11 that Article 12(3) 'authorises the State to restrict these rights only to protect national security, public order (ordre public)' and to be permissible, 'restrictions must be provided by law, must be necessary in a democratic society.' Reproduced in Sarah Joseph, Jenny Schultz and Melissa Castan, The International Covenant on Civil and Political Rights: Cases, Material's, and Commentary (2 $2^{\text {nd }}$ edn, OUP 2004) 361.

${ }^{67}$ ICCPR (n 26) Article 12(3); see also, Myriam Feinberg, 'International Counterterrorism - National Security and Human Rights - Conflicts of Norms or Checks and Balances' (2015) 19 International Journal of Human Rights 388; Alexander Orakhelashvili, 'The European Convention on Human Rights and International Public Order' (2003) 5 Cambridge Yearbook of European Legal Studies 237; see also, Jan Oster, 'Public Policy and Human Rights' (2015) 11 Journal of Private International Law 542 (discussing human rights in the public policy perspective as oppose to the 'public order' approach that can be linked to national security, as I am arguing).

68

On this point, see also Manfred Nowak, U.N. Covenant on Civil and Political Rights: CCPR Commentary (Kehl: Engel Publishing 1993) 212; for general commentary, see Joseph (n 35); Markus Schmidt, 'Reservations to United Nations Human Rights Treaties - the Case of the Two Covenants' in J Gardner, Human Rights as General Norms and a State's Right to Opt Out: reservations and Objections to Human Rights Conventions (London: BIICL 1997) 20. 
a scenario such as this, it is for other branches of international law to respond. Then again, other such branches of international law would not be able to determine the obligations of the ICCPR in relation to external threats that pose a problem to human rights based on national security.

It is these exceptions to human rights in international legal instruments such as the ICCPR which have actually provided for the direct linkage between the policy and legal objectives of these two fundamental functions of the State. The State must, on the one hand, ensure that basic freedoms and rights are guaranteed and that its citizens can enjoy such rights. ${ }^{69}$ The State, however, is in a position to determine the limits of those rights, as long as those limits are justified using the language of national security.$^{70}$ This is where the complexity of the interactions between human rights and national security norms becomes challenging, as international law then interacts with domestic law.

Moreover, one cannot deny the fact that the exceptions in international human rights instruments are also a reflection of the broader corpus of international law, where varying approaches and interpretations often create the operating space for national security within the realm of international law. In essence, national security gives rise to grey zones in international law, and international law, in turn, facilitates how the norms of national security function as a means of enforcing the sovereignty of the State. ${ }^{71}$

Furthermore, given that it is domestic law that, on most occasions, implements international law, one can hardly ignore the political ramifications of transplanting international norms onto domestic systems, especially if there are concerns about their implications or motives. Thus, a clash of the moral and political objectives of international norms and domestic policy norms can lead to domestic norms gaining the upper hand. ${ }^{72}$

Furthermore, in the case of human rights at the domestic level, human rights norms relate to the criminal justice system, ${ }^{73}$ whose primary objective is the maintenance of law

69 See, for example, Jeremy Waldron, 'Security and Liberty: The Image of Balance' (2003) 11 Journal of Political Philosophy 181.

70 See Joseph Zand, 'Article 15 of the European Convention on Human Rights and the Notion of State of Emergency' (2014) 5 Journal of the Faculty of Law of Inou University 159; LC Green, 'Derogation of Human Rights in Emergency Situations' (1978) 16 Canadian Yearbook of International Law 82; Scott Sheeran, 'Reconceptualising States of Emergency under International Human Rights Law: Theory, Legal Doctrines and Politics' (2013) 34 Michigan Journal of International Law 491; Mohamed El Zeidy, 'The ECHR and States of Emergency: Articles 15-A Domestic Power of Derogation from Human Rights Obligations' (2002) 11 Michigan State University Detroit College of Law Journal of International Law 261.

71 See Hannes Schloemann and Stefan Ohlhoff, "'Constitutionalization" and Dispute Settlement in the WTO: National Security as an Issue of Competence' (1999) 93 American Journal of International Law 424, 426: 'Wherever international law is created, the issue of national security gives rise to some sort of loophole, often in the form of an explicit national security exception. ...As long as the notion of sovereignty exerts power within this evolving system, national security will be an element of, as an exception to, the applicable international law.'.

72 See generally, Naomi Roht-Arriaza, 'Just a "Bubble"? Perspectives on the Enforcement of International Criminal Law by National Courts' (2013) 11 Journal of International Criminal Justice 537; Hisashi Owada, 'Problems of Interaction Between the International and Domestic Legal Orders' (2014) 5 Asian Journal of International Law 246.

73 See generally, John Andrews, Human Rights in Criminal Procedure: A Comparative Study (Martinus Nijhoff 1982); Andrew Ashworth, Human Rights, Serious Crime and Criminal Procedure (London: Sweet and Maxwell 2002). 
and order. However, the trend towards the conditionalisation of human rights has in some ways excluded criminal law from direct conflict with constitutions. ${ }^{74}$

In the ECHR, as amended by Protocol $15,{ }^{75}$ which is perhaps the most ubiquitous of the descendants of the UDHR, there are four references to national security (in Articles $6(1), 8(2), 10(2)$ and 11(2)), largely reinforcing the original text of the ECHR of 1950. In terms of express limitations on human rights, only one provision of the ECHR, Article 9(2), mentions that limitations may be placed on freedom of thought, conscience and religion: 'Freedom to manifest one's religion or beliefs shall be subject only to such limitations as are prescribed by law and are necessary in a democratic society in the interests of public safety, for the protection of public order, health or morals, or for the protection of the rights and freedoms of others.' Interestingly, this provision does not include the term 'national security'. Rather, a longer list of related matters, which are vague enough to be interpreted as including national security, were listed alongside the close ally to national security: public order. Therefore, in one sense, the practicing of religion can pose a national security threat under the ECHR in the same way that detention is permissible if it is to prevent the spread of infectious diseases and protect public health. ${ }^{76}$

\section{National Security, Human Rights and International Law: A Forward and Critical Outlook}

Any discussion on human rights and the state of international law is often shrouded in some form of agenda-setting. There is generally self-interest, moral, political and other interests behind the human rights narrative. Thus, a paper such as this must escape the (normative) agenda-setting of the human rights discourse with some form of radical departure from critique or theoretical propositions.

However, that too will prompt the reader to question my agenda. In truth, there is no agenda; rather, I am attempting to put into perspective the normative and doctrinal functions of the human rights discourse in international law with some critical observations. Moreover, these observations are from the point of view of national security. If there should ever have been a different agenda on my part, it is perhaps a sceptical loathing of the politics of the international human rights movement which, if I may borrow David Kennedy's take, is a part of the problem, ${ }^{77}$ and the need for change across the entire international human rights regime, both in a legal and political sense.

However, as an academic paper, perhaps it is safer to resort to diplomatic and cunning theoretical perspectives, however far-fetched some may seem. However, therein lies another problem: theoretical propositions or critical observations can hardly achieve much in terms of practical solutions. In this regard, I find it more prudent to endorse a statist logic of human rights put forward decades ago by Richard Falk. ${ }^{78}$

74 For some discussion see, for example, Rett Ludwiokowski, 'Constitionalization of Human Rights in PostSoviet States and Latin America: A Comparative Analysis' (2004) 33 Georgia Journal of International and Comparative Law 1.

75 Protocol 15 was adopted in June 2013 and provides for, among other things, the margin of appreciation principle; for discussion, see Nikolas Vogiatzis, "When "Reform" Meets "Judicial Restraint": Protocol 15 Amending the European Convention on Human Rights' (2015) 66 NILQ 127.

76 Enhorn $v$ Sweden App No 56529/00 (ECtHR, 25 January 2005).

77 On this, see David William Kennedy, 'The International Human Rights Movement - Part of the Problem?' (2002) 15 Harvard Journal Human Rights 1011.

78 Richard Falk, Human Rights and State Sovereignty (New York: Holmes and Meier Publishing 1981) - the chapter 'Theoretical Foundations of Human Rights' was republished in Richard Pierre Claude and Burns Weston, Human Rights in the World Community (University of Pennsylvania Press 1989) 29-41 and it is this version I rely on to interpret Falk. 
Falk provides in his book a structural formation of human rights in world politics and not purely legal constructs. To this end, Falk argues that there six types of logics, or theoretical views, that make up human rights: statist, hegemonial, naturalist, supranaturalist, transnational, and populist, and that these logics reflect the normative aspiration and political constraints of States in international legal relations. For my purpose, the focus on State sovereignty is one of the highlights of the book and, in a provocative chapter, Falks delineates some of the hard political realities of State sovereignty in the world order, which in turn affects how human rights are implemented. This statist approach to human rights, according to Falk, in some ways inhibits the proper functioning of the State or at least is incompatible with how States operate, since human rights encroach upon State sovereignty. Although Falks' work appeared during the Cold War, it still has some relevance, at least in relation to the way I am framing human rights and national security in this article. In this regard, international norms such as human rights fit into a global paradigm only when a 'particular government so agreed.' ${ }^{19}$ Furthermore, 'the statist matrix of political life also means that the most substantial contributions to the realization of human rights arise from the internal dynamics of domestic politics. ${ }^{80}$ In other words, through Falk's comments, one can observe that States are motivated by their own internal selfish desire for power and are not genuinely committed to global human rights norms.

One way of interpreting this argument is that States do engage with global norms of human rights but do so half-heartedly: with one foot in and one foot out. Moreover, even when States engage with global human rights norms through treaties, they often fall back on the most diplomatic and legally cunning way to reflect their partial commitments to global human rights norms: limitations and restrictions based on national security. ${ }^{81}$

In choosing the statist logic, or theoretical view of human rights, I am in a position to relabel it as a human right by the State to national security under the cloak of Dworkinian language. These perspectives, I posit, offer some of the best hopes for balancing national security and human rights in international law.

\section{A. The Threat of Human Rights: A Right to National Security?}

Should States be subject to a (human) right to national security? Or, taken in context, should States have a right to national security by arguing that human rights form part of that right when the individual concerned breached their own human rights? Seen another way, and taking Kennedys' view into consideration, I argue in this section of the article that human rights are a threat to national security.

Although, in general, sovereign States enact legislation as part of their territorial and sovereign function, the argument should not be seen as such: that is, States can enact any legislation they want without the requirement to do so as a form of a right, but as their prerogative. Rather, the argument should be that States enact legislation in light of human rights laws as a right within that paradigm. The reason for this is because national security and human rights are fundamentally different norms whose ideologies continue to clash

79 ibid 30.

80 ibid 31.

81 This is based on the argument that human rights treaties such as the ECHR in Article 15 allows States to derogate from human rights obligations, and cases such as Lawless $v$ Ireland in which the court confirmed derogations based on 'emergency situations' Lawless v Ireland (No 1) (1960) 1 EHRR 1 para 28; for general discussions on reservations to human rights treaties see, for example, Massimo Coccia, 'Reservations to Multilateral Treaties on Human Rights' (1985) 15 California Western International Law Journal 1; Eric Neumayer, 'Qualified Ratification: Explaining Reservations to International Human Rights Treaties' (2007) 36 Journal of Legal Studies 397. 
and any form of compromise requires one regime giving into the other by using the norms (and the logics) of the other regime.

Thus, national security should use the regime and language of human rights as a right to national security, or the human rights regime should use the language of national security as a right to human rights. It is the former that I am advocating. There is more resonance in this argument compared to the latter, given that the human rights that individuals enjoy, to paraphrase Dworkin, can only be restricted by other human rights, ${ }^{82}$ not by national security.

The two regimes, national security and human rights, offer different forms of protection. The regime of national security arguably offers protection for the State, and the regime of human rights protects individual liberties. Naturally, considering these two regimes and their objectives is always a balancing act. Thus, whether it is an 'emergency situation' or other form of public order concern, national security involves the full power of the State to restrict individual liberty even in peace time. On the other hand, human rights during peacetime are usually restricted if the State invokes a national security issue. Thus, in some Dworkinian sense, national security interests will always result in the individual rights later being truncated in the name of national security ${ }^{83}$ Taking Dworkin seriously, therefore, suggests that the rights that individuals enjoy under the rubric of constitutional and human rights are only put in place to create a social illusion in which the individual can operate with the belief that their rights are greater than those of the State.

In one sense, Dworkin's arguments support the view that States should apply the regime and language of human rights to the concept of a right to national security. Thus, in a Dworkinian sense, and under extreme circumstances, 'if the right were so defined, the cost to society would not simply be incremental, but would be of a degree far beyond the cost paid to grant the original right, a degree great enough to justify whatever assault on dignity or equality might be involved. ${ }^{184}$ When this view in taken into account, States may rely on their right to national security as a right of the State, by engaging the language of human rights.

The State right to national security is a strong right, ${ }^{85}$ as opposed to a weak right. For instance, as shown in the ICCPR and other regional derivatives such as the ECHR, there are provisions, such as Article $8 \mathrm{ECHR}$, that allow for human rights to give way to national security exceptions. On some occasions, the European Court of Human Rights has acknowledged the precedence of national security, such as in relation to State secrets and limits to human rights claims. For instance, in Moiseyev $v$ Russia, ${ }^{86}$ the court concedes that national security considerations, under certain circumstances, can limit procedural restrictions (in human rights claims) in cases where State secrets are involved. It is not often that national security restrictions are invoked in the ECtHR. Then again, faced with the reality of national security, even if it concerns an external State such as Russia, the ECtHR gives way to realism. In the US, in 1981, the US Supreme Court seemed to have the perfect answer for issues on national security: 'matters intimately related to questions of foreign

82 Ronald Dworkin, Taking Rights Seriously (Duckworth 1977) 200; see, however, Christopher McCrudden, 'A Common Law on Human Rights? Transnational Judicial Conversations on Constitutional Rights' (2000) 20 Oxford Journal of Legal Studies 499.

83 Dworkin (n 82) 200 noting: 'although great social cost is warranted to protect the original right, this particular cost is not necessary'.

84 ibid.

85 On the notion of strong rights, see Ashworth (n 73) 76.

86 Moiseyev v Russia App no 62936/00 (ECtHR, 9 October 2008). 
policy and national security are rarely proper subjects for judicial intervention' ${ }^{87}$ However, that is the no longer the situation in the post-9/11 world.

\section{B. Statist Logic and the Right to Restrict Human Rights}

Based on the statist argument that Falk advances, and when seen in the light of the broader politics of international law, sovereign States, no matter the circumstances, enjoy the right to legislate, even to make legislation that restricts human rights. Thus, the statist logic shows that States engage in organised hypocrisy when it comes to international human rights obligations that they willingly sign ${ }^{88}$ but enforce only in ways that are beneficial to the State. This observation is not about undemocratic States, such as the Democratic Peoples' Republic of Korea, but is rather about States in the West that take the moral high ground when it comes to human rights.

Restricting human rights in the name of national security (or its close ally, ordre public) does not mean that a State is undemocratic or authoritarian. It simply means that restrictions on human rights in fact, when temporary or done in the name of national security, make it harder to protect those very same human rights. However, by doing so, States see themselves as defending human rights - safeguarding the State from external and internal threats. Individuals and non-State actors cannot defend human rights on behalf of the State. States defend their human rights, via restrictions, in their own interests from external threats that can pose severe harm to national security, such as the threat of war or engagement in conflict, including conflicts that occur in cyberspace.

Another mortal enemy from which States defend human rights through imposing restrictions is the internal threat to national security posed by internal actors of the human rights systems. These actors may vary from non-governmental organisations, opposition groups, activists' lawyers, the intelligentsia and those seeking public inquiries into States' armed forces in overseas operations. ${ }^{89}$

As a State may defend its human rights through restrictions, that State should not be able to criticise other States who have done the same. States in contemporary international legal relations vary by their democratic modus operandi and, as such, they tend to have different approaches to the defence of human rights through imposing restrictions on national security grounds. In fact, it is the various norms and moralities in different States that allows them to defend human rights by imposing such restrictions and actually allows States to cooperate when they engage in the defence of human rights through restrictions.

Some defences of human rights through restrictions include the Rendition programme and black sites for torture during the war on terror, where legal questions surrounding the detention and treatment of detainees and enhanced interrogation

87 Haig v Agee, 453 US 280292 (1981).

88 See also, Christine Wotipka and Kiyoteru Tsutsui, 'Global Human Rights and State Sovereignty: State Ratification of International Human Rights Treaties, 1965-2001' (2008) 23 Sociological Forum 724.

89 For example, UK armed forces and alleged human rights abuses in Iraq. Even if such cases were to make it to an international tribunal, a more problematic question would arise as to what extent those tribunals would have jurisdiction; for comments on a similar point from an interdisciplinary perspective, see Andrea Birdsall, The International Politics of Judicial Intervention: Creating a More Just Order (Routledge 2009); see also Sarah Sewall and Carl Kaysen (eds), The United States and the International Criminal Court: National Security and International Law (Oxford: Rowman and Littlefield 2000); Rebecca Sanders, 'Exceptional Security Practices, Human Rights Abuses, and the Politics of Legal Legitimation in the American "Global War on Terror"' (PhD thesis, University of Toronto 2012). 
techniques were suspended regarding non-combatant suspects. ${ }^{90}$ Thus, when one suspect, al-Jeddawi, was taken by American intelligence operatives to Jordan during the war on terror, it was precisely because such tortures could not be morally possible (via public acknowledgment) in the US, as opposed to Jordan, where such practices were well known to have taken place. ${ }^{91}$ Both the US and Jordan, on that occasion, I posit, were defending their human rights by imposing restrictions for the same strategic goal: national security via the war on terror. As such, it would have been unfriendly for the US to publicly denounce the human rights record of Jordan while engaging Jordan to carry out activities that were deemed to violate basic human rights and international legal obligations.

From a legal point of view and also in accordance with international human rights obligations, the rendition and black sites operations were feasible within legal limits, provided that those acts were a response to the national security threat to the US. This is even more so if the national security threat was defined, as above, to be high-level or, as the Office of the Legal Counsel to the White House observed in 2002, as a national security necessity: 'The necessity defense may prove especially relevant [...] the purpose behind necessity is one of public policy. ${ }^{92}$ Therefore, defending human rights via restrictions is justified when confronted with a high-level national security threat, such as an attack or other form of aggression which surveillance and intelligence can prevent. As the Bybee Memo further notes: 'If intelligence and other information support the conclusion that an attack is increasingly certain, then the necessity for the interrogation will be reasonable. ${ }^{93}$

90 See generally David Weissbrodt and Amy Bergquist, 'Extraordinary Rendition: A Human Rights Analysis' (2006) 19 Harvard Human Rights Journal 123; K Levit, 'The CIA and the Torture Controversy: Interrogation Authorities and Practices in the War on Terror' (2005) 1 Journal of National Security Law \& Policy 341; Alan Clarke, 'Rendition to Torture: A Critical Legal History' (2009) 62 Rutgers Law Review 1; Louis Fisher, 'Extraordinary Rendition: The Price of Secrecy' (2008) 57 American University Law Review 1405.

91 There are sketchy details surrounding the exact identity of al-Jeddawi, whose real name can either be, but not limited to, Ibrahim 'Abu Mu'ath' al-Jeddawi or Ahmad Ibrahim Abu al-Hasana. Apart from his identity, there are also few details on his alleged abduction or rendition; for some discussion see generally Jillian Button, 'Spirited Away (Into a Legal Black Hole): The Challenges of Invoking State Responsibility for Extraordinary Rendition' (2007) 19 Florida Journal of International Law 531; Leila Sadat, 'Ghost Prisoners and Black Sites: Extraordinary Rendition under International Law' (2007) 15 ILSA Quarterly 9; Naureen Shah, 'Knocking on the Torturer's Door: Confronting International Complicity in the U.S. Rendition Program' (2007) 38 Columbia Human Rights Law Review 581; Alan Clarke, 'Rendition to Torture: A Critical Legal History' (2010) 62 Rutgers Law Review 1; Timothy Synhaeve, 'Take the War on Terror to the Court: A Legal Analysis on the Right of Reparation for Victims of Extraordinary Renditions' (2011) 5 Vienna Journal on International Constitutional Law 439; Bruce Zagaris, 'Introductory Note to the European Court of Human Rights: Othman (Abu Qatada) v. the United Kingdom' (2013) 52 International Legal Materials 496, 534, discussing renditions to Jordan.

92 US Department of Justice (Jay Bybee) Office of the Legal Counsel, Memorandum for Alberto R Gonzales Counsel to the President (1 August 2002) 40; see also, US Department of Justice (John Yoo) Office of the Legal Counsel, Memorandum for William J Haynes II, General Counsel of the Department of Defense (14 March 2003) 61, noting that the US Administration should be given discretionary powers 'to respond to the grave threat of national security' posed by the War on Terror; other legal memorandums produced by US government functionaries during the war on terror include US Department of Justice (Steven Bradbury) Office of the Legal Counsel, Memorandum for John A Rizzo, Senior Deputy General Counsel of the Central Intelligence Agency (30 May 2005); for general commentary see, for example, Michael Scharf, 'International Law and the Torture Memos' (2009) 42 Case Western Reserve Journal of International Law 321, 335: 'international rules that constrain U.S: power and thus compromise national security are not really binding'; Jack Goldsmith and Eric Posner, The Limits of International Law (OUP 2005) 103: 'Powerful States may do better by violating international law when doing so shows that they will retaliate against threats to national security.'.

93 Jay Bybee (n 92) 44; see also Ryan Goodman, 'Rationales for Detention: Security Threats and Intelligence Value' (2002) 96 American Journal of International Law 531. 
The rights that the individual enjoys under those circumstances would therefore give way to high-level concerns of national security - a right of the State.

Another argument that supports the statist logic on the restriction of human rights is the broader question of sovereignty and States' commitments to international legal obligations via human rights treaties. Although States have signed up to numerous human rights treaties, those States have not surrendered their sovereignty to the international human rights system..$^{94}$ Unlike other regimes in the international legal plane, such as the world trade organization (WTO), that have a dispute settlement body, the international human rights system is fragmented, and acts as a political tool through which States are able to use and patch leakages in their human rights record.

The International Criminal Court (ICC) is the nearest institution to an international human rights court. However, the ICC has many weaknesses and, with its limited mandate (the US is not party to the ICC Statute), does not fit the bill as an international human rights court. This gap in the administration of justice on the international legal plane concerning human rights then leaves States' sovereignty intact. As a result of this, States are able to spin the sovereignty wheel in favour of the defence of human rights by imposing restrictions on the grounds of national security. In this regard, an international or global legal order of human rights is purely utopian as States, in Pufendorfian terms, are the highest moral and legal authorities. ${ }^{95}$

The debate on sovereignty over human rights is well-catalogued, ${ }^{96}$ so I am not going to bolster it any further here. To conclude this viewpoint, sovereignty, human rights and national security form, define and cosmopolitise the nation State. In this race to cosmopolitise, the State embraces the values of the UN Charter, ${ }^{97}$ the UN being a sovereign and equal entity in international legal relations.

The State further shapes those legal relations by committing to human rights obligations, at the same time invoking its sovereign and equal status, implying that there is an extent to which it is committed. In this regard, sovereignty, human rights and national security are the pillars on which the legitimate authority of the State is entrenched in international law. Without all three, the State can collapse on nebulous foundations. By committing to international human rights obligations, the State lays claim to civilised cooperation. As such, the State's claim is well-grounded in the customary principles of international law.

94 For a sociological, take on this point see, for example, Wade Cole, 'Sovereignty Relinquished? Explaining Commitment to the International Human Rights Covenants, 1966-1999' (2005) 70 American Sociological Review 472.

95 See Richard Devetak, 'Between Kant and Pufendorf: Humanitarian Intervention, Statist AntiCosmopolitanism and Critical International Theory' (2007) 33 Review of International Studies 151, arguing that Pufendorf has always defended the political morality of authority.

96 See, for example, Noha Shawki and Michaelene Cox (eds), Negotiating Sovereignty and Human Rights: Actors and Issues in Contemporary Human Rights Politics (Ashgate 2009); Patrick Macklem, The Sovereignty of Human Rights (OUP 2015); Anne Peters, 'Humanity as the A and $\Omega$ of Sovereignty' (2009) 20 European Journal of International Law 513; Panu Minkkinen, 'The Ethos of Sovereignty: A Critical Appraisal' (2007) 8 Human Rights Review 33; Natsu Taylor Saito, 'The Plenary Power Doctrine: Subverting Human Rights in the Name of Sovereignty' (2002) 51 Catholic University Law Review 1115; Jack Donnelly, 'State Sovereignty and International Human Rights' (2014) 28 Ethics and International Affairs 225; Kurt Mills, 'Reconstructing Sovereignty: A Human Rights Perspective' (1997) 15 Netherlands Quarterly of Human Rights 267; W Michael Reisman, 'Sovereignty and Human Rights in Contemporary International Law' (1990) 84 American Journal of International Law 866.

97 Charter of the United Nations (adopted 26 June 1945, entered into force 24 October 1945) 1 UNTS XVI, Article 2(1). 
As a sovereign State within the system of international law, the State then further buttresses its authority by creating and conforming to constitutional-like principles in the domestic setting that guarantee the freedom and fundamental values of its citizens. This in turn creates the legitimacy of the State to operate on the international legal plane. The final pillar of national security allows the State to demonstrate that it enjoys sovereignty over its legislative actions and is able to shape the contours of the international legal system when faced with external threats. States are thus the creators and enforcers of international law. Thus, a threat or an act of aggression that can destabilise the national security of the State can force the State to respond with the defence of human rights (freedom and fundamental values) via restrictions by invoking national security as a reasonable cause.

Part of the response to external threats involves legislation that questions the very existence of human rights and the prerogative of the State as a sovereign nation. In the post-9/11 world, the rise of security laws has shown how States react to national security threats and aggressions. ${ }^{98}$ These legislative reactions, that one commentator has termed as 'juris-generative' ${ }^{99}$ have spilled over to other nation States and within international lawmaking, the result of which is the cosmopolitisation of security laws.

The post-9/11 world has seen a rapid expansion of security laws, not only in the US but at the global level, on a scale that saw 'legalism [...] abounded, not receded.' 100 The multiplicity of international security laws at the global level ${ }^{101}$ has seen States, both strong and weak, sign onto these global standards or adjust their own domestic laws ${ }^{102}$ to meet the global standards that first emerged from the US Patriot Act. ${ }^{103}$ The multiplicity of such abounded legalism in international security underwent mitosis in an eco-system set on replication. Such mitosis is best characterised as such:

as the meaning in a nomos disintegrates, we seek to rescue it - to maintain some coherence in the awesome proliferation of meaning lost as it is created - by unleashing upon the fertile but weakly organized juris-generative cells an organizing principle itself incapable of producing the normative meaning that is life and growth. ${ }^{104}$

The securitisation of laws at the global level has allowed States to engage with the language of human rights so as to a posit a right to national security, and enabled them to engage in mass surveillance on a scale that, in some countries, does have the tacit approval of

98 For example, where countries were required to enact or amend legislation to comply with anti-terror financing or extradition requirements; see, for example, Navin Beekarry, 'The International Anti-Money Laundering and Combating the Financing of Terrorism Regulatory Strategy: A Critical Analysis of Compliance Determinants in International Law' (2011) 31 North-Western Journal of International Law and Business 137; for an eloquent reading of security laws, see Kim Lane Scheppele, 'The Empire of Security and the Security of Empire' (2013) 27 Temple International and Comparative Law Journal 241.

99 Sanders (n 89) 346.

${ }^{100}$ Sanders (n 89) 346; on the origins of the term see Robert Cover, 'The Supreme Court 1982 Term Foreword: Nomos and Narrative' (1983) 97 Harvard Law Review 4, 15: 'law is jurisgenerative by a process of juridical mitosis.'.

${ }^{101}$ See also Kim Lane Scheppele, 'The International State of Emergency: Challenges to Constitutionalism After September 11' (Working Paper, 2006) 46, describing American (international) security legislative making as 'enormous outbursts of lawmaking'.

102 Scheppele (n 98) 247 discussing 'global security law'.

${ }^{103}$ The USA Patriot Act, Pub L No 107-56, 11 Stat 272 (2001).

104 Cover (n 100) 16. 
citizens, ${ }^{105}$ regardless of whether or not human rights concerns are central to their notion of national security.

\section{Cybernetic Cold War and Organised Hypocrisy}

Over the years, as the issue of human rights and national security was debated in the legal literature, ${ }^{106}$ the courts of justice and public opinion were engaged in practical national security issues such as terrorism, ${ }^{107}$ counter-terrorism, ${ }^{108}$ torture ${ }^{109}$ and deportation. ${ }^{110}$ In recent years, online privacy and whistleblowing, and the extent of national security within these two areas ${ }^{111}$ have also generated legal and political debates. ${ }^{112}$

As a direct result of these developments, for example in the normative jurisprudence of the American legal system, privacy protection and how national security laws affect it must also come to terms with the first and Fourth Amendments of the American constitution. This is most evident in whistleblowing after the Snowden revelations. ${ }^{113}$ However, because there are a number of specific issues that are embodied in the broad concept of national security that the domestic State must respond to, exemptions that are related to privacy per se and the objectives of national security are often not easy to define. Instead, they are situated between the untamed worlds of public policy (ordre public), national security and human rights.

What is, however, significant is that the first act of response by the domestic State to national security threats caused by whistleblowing, for example, is to mobilise State resources to combat such threats, ${ }^{114}$ and also respond with legislation that limits the right

${ }^{105}$ For example, on 25 September 2016, Switzerland voted for mass surveillance laws that gives the security forces greater powers to monitor private communications, see Federal Act on the Intelligence Service (Intelligence Service Act/ISA).

106 See also, Itzhak Zamir, 'Human Rights and National Security' (1989) 23 Israel Law Review 375.

${ }^{107}$ Richard Wilson (ed), Human Rights in the 'War on Terror' (CUP 2009).

${ }^{108}$ Fergal Davis and Fiona de Londras, Critical Debates on Counter-Terrorism Judicial Review (CUP 2014).

${ }^{109}$ See generally, Jeremy Waldron, 'Torture and Positive Law: Jurisprudence for the White House' (2005) 105 Columbia Law Review 1681.

${ }^{110}$ See generally, Elspeth Guild and Paul Minderhoud, Security of Residence and Expulsion: Protection of Aliens in Europe (Kluwer 2001); Elspeth Guild, Security and Migration in the $21^{\text {st }}$ Century (Polity Press 2009).

${ }^{111}$ See also, Sahar Aziz, 'Security and Technology: Rethinking National Security' (2015) 2 Texas A\&M Law Review 791; P Sean Morris, "WWar Crimes” Against Privacy: The Jurisdiction of Data and International Law' (2016) 17 Suffolk Journal of High Technology Law 1.

${ }^{112}$ See, for example, Mark Friedman, 'Edward Snowden: Hero or Traitor - Considering the Implications for Canadian National Security and Whistleblower Law' (2015) 24 Dalhousie Journal of Legal Studies 1; Melanie Reid, 'Government Secrets: The Public's Misconceptions of the Snowden Disclosures' (2015) 3 Lincoln Memorial University Law Review 36; Stephen Vladeck, 'Big Data Before and After Snowden' (2014) 7 Journal of National Security Law and Politics 333; Zachary Smith, 'Privacy and Security-Post Snowden: Surveillance Law and Policy in the United States and India' (2014) 9 Intercultural Human Rights Law Review 137; Jill Frayley, 'The Government Contractor Defense and Superior Orders in International Human Rights Law' (2009) 4 Florida A\&M University Law Review 43.

${ }^{113}$ See generally, Margaret Hu, 'Taxonomy of the Snowden Disclosures' (2015) 72 Washington and Lee Law Review 1679; Jason Zenor, 'Damming the Leaks: Balancing National Security, Whistleblowing and the Public Interests' (2015) 3 Lincoln Memorial University Law Review 61; Susan Opt, 'Naming Edward Snowden's Actions as Heroic or Villainous: Implications for Interpreting First Amendment Trends' (2015) 49 First Amendment Studies 98.

${ }^{114}$ See, for example, the then SIGNINT Statute 18 USC $§ 798$ (2006); after the Snowden revelations, the enactment of the USA Freedom Act (2015) is one of the primary legislative responses, see The USA Freedom Act HR 2048, Pub L 114-23; hence, the State must on the one hand protect its national security and or 'classified' information, but at the same time engage in some form of transparency; see generally 
to online privacy. ${ }^{115}$ State resources are generally coordinated via agencies responsible for intelligence, both internally and externally. The internal security apparatus can be anything from the Internal/Interior/Home Affairs or National Security Ministries, which include the police, justice departments and the intelligence agencies responsible for internal intelligence.

In this regard, one must always view national security as a concept that cannot be isolated from its political masters and, therefore, the role of national security apparatus should also be viewed in its wider policy context. ${ }^{116}$ At the same time, external intelligence responses can raise questions on their interaction with human rights and present a clear and present danger to human rights values as such. These interactions may vary from the very nature of collecting intelligence, to surveillance and modern cyber-communications that raise concerns regarding online privacy.

To put things in perspective regarding the State response to, for example, whistleblowing, the general norms of politics in international law should also be contextualised. This is because these often meet realism head on and, as result, finding a proper legal solution to protect whistleblowing from a human rights perspective is not that easy; especially when such whistleblowing has been determined as treasonous from a national security perspective. International law and the underlying international relations that require legal attention regarding whistleblowing are always issues of complicated realpolitik. Some of the crusades to leak State secrets can be compared to scripts from some of the best spy novels or fiction films.

Through the emerging constitionalisation of global security laws as a result of the war and terror and the Snowden disclosures, the international legal system was not prepared to handle the more serious developments in global affairs that require States to respond decisively and to use international law in that response. How the leaders of States respond in terms of both policy and language to global developments is important. In other words, using the language of international law to denounce one State but using the same language to praise another State is nothing but a form of hypocrisy in the international system. This was most evident in the Snowden affairs given that the self-interest of the United States was undermined. It was a moment that allowed, for example, Vladimir Putin of Russia to quip that the West (America and Europe) suddenly remembered international law during the Crimean crisis of $2014 .{ }^{117}$ Putin was justifying why Russia annexed

for some discussions on these issues Richard Hyde and Ashley Savage, 'The Response to Whistleblowing by Regulators: A Practical Perspective' (2015) 35 Legal Studies 408; Stephen Vladeck, 'The Espionage Act and National Security Whistleblowing After Garcetti' (2008) 57 American University Law Review 1531; Colin McLaughlin and Michael Scharf, 'On Terrorism and Whistleblowing' (2007) 38 Case Western Reserve Journal of International Law 567; Alexander Kasner, 'National Security Leaks and Constitutional Duty' (2015) 67 Stanford Law Review 241; Ashley Deeks, 'An International Legal Framework for Surveillance' (2015) 55 Virginia Journal of International Law 291; for discussions on the Sarbanes-Oxley Act of 2002, see Terry Morehead, 'Sox and Whistleblowing' (2007) 105 Michigan Law Review 1757.

115 See also Aziz (n 111); Stephen Schulhofer, 'An International Right to Privacy? Be Careful What You Wish For' (2016) 14 ICON 238; Paul Finkelman and Abraham Wagner, 'Security, Privacy, and Technology Development: The Impact on National Security' (2015) 2 Texas A\&M Law Review 597; Cynthia Laberge, 'To What Extend Should National Security Interests Override Privacy in a Post 9/11 World' (2010) 3 Victoria University of Welling Working Paper Series 1.

116 See, for example, L Lustgarten, 'National Security and Political Policing: Some Thoughts on Values, Ends and Law' in Jean-Paul Brodeur, Peter Gill and Dennis Tollborg (eds), Democracy, Law and Security (Ashgate 2003) 319-334.

117 Vladimir Putin, Address by President of the Russian Federation (regarding the Crimean Referendum of 16 March 2014 to Join Russia) (Moscow, 18 March 2014) <eng.kremlin.ru/transcripts/6889> (accessed 1 August 
(incorporated) the Crimean Peninsula in 2014 and was also reacting to the hypocrisy of the West because the West, he implied, tends to use international law in its own selfinterest to justify any actions they undertake outside of their borders; yet when other countries justify their actions under international law, then those countries are deemed to be in 'breach' thereof. Putin, himself a trained (international) lawyer and master spy, knows that international law is a questionable project and in a troubled state because the double standards that have plagued the science and practice of international law makes it seem like a system of organised hypocrisy. ${ }^{118}$

The reference to Vladimir Putin, the restorer of Russian power in contemporary international law and relations, ${ }^{119}$ carries a certain weight because it was Putin who granted Snowden (temporary) political asylum in Russia 2013. ${ }^{120}$ Why did Snowden need political asylum? It so happened that in that same year, Snowden blew the whistle on the mass surveillance and data grabbing (retention) techniques that the US intelligence apparatus used to collect data and gather intelligence from all over the world. This data was then stored in fortified US data repository banks that were impenetrable even to the forces of nature. ${ }^{121}$

Snowden became the hero (for freedom of information activists) and Putin, in an ironic twist, became the great Statesman and saviour of the (Western) freedom of information. Naturally, all of the above is arguable, but the larger point here is that States have embarked on mass data surveillance and data-grabbing techniques in recent years, as the Snowden files revealed. Those data surveillance and grabbing techniques have been carried out in the name of national security. ${ }^{122}$

What links both Putin and Snowden is their known work as intelligence operatives for their respective governments; Putin for the former KGB of the Soviet Union and Snowden for the American mega intelligence apparatus (via a temporary contract with an external source), which includes the Central Intelligence Agency (CIA) and the National Security Agency (NSA). ${ }^{123}$ The role of the NSA involves mainly telephone eavesdropping

2020): 'They say [Russia is] violating norms of international law. Firstly, it's a good thing that they at least remember that there exists such a thing as international law - better late than never'; see also J Goldsmith and E Posner, 'Moral and Legal Rhetoric in International Relations: A Rational Choice Perspective' (2002) 31 Journal of Legal Studies 115.

118 On this latter point see, for example, Stephen Krasner, Sovereignty: Organized Hypocrisy (Princeton University Press 1999) 212 discussing various contradictory norms such as human rights, and also pointing out that 'Soviet rulers were motivated by both concerns about national security and the legitimacy of Marxism-Leninism'.

119 See generally, Maria Engstrom, 'Contemporary Russian Messianism and New Russian Foreign Policy' (2014) 35 Contemporary Security Policy 356; Ingmar Oldberg, 'Russia's Great Power Strategy under Putin and Medvedev' (2010) UI Occasional Papers 1; Natalia Morozova, 'Geopolitics, Eurasianism and Russian Foreign Policy under Putin' (2009) 14 Geopolitics 667.

120 Jacob Stafford, 'Gimme Shelter: International Political Asylum in the Information Age' (2014) 47 Vanderbilt Journal of Transnational Law 1167, 1171 (discussing Snowden's political asylum application); William Herrington, 'Snowed in in Russia: A Historical Analysis of American and Russian Extradition and the Snowden Saga Might Impact the Future' (2015) 48 Washington University Journal of Law \& Policy 321.

${ }^{121}$ See, for example, Klayman v Obama, 957 F Supp 2d 1 (2013) challenging the constitutionality and statutory authorisation of certain intelligence-gathering practices by the United States government relating to the wholesale collection of the phone record metadata of all US citizens.

122 The Swiss Federal Act on the Surveillance of Mail and Telecommunications Traffic (2016); the proposed Investigatory Powers Bill (2016) (UK); so-called snooping laws.

${ }^{123}$ For Snowden's connection to the NSA see, for example, Hu (n 113) 1681; on the background of Putin, see, for example, Dale Herspring and Jacob Kipp, 'Understanding the Elusive Mr. Putin' (2001) 48 Problems of Post-Communism 3. 
and cybernetic activities. ${ }^{124}$ Nowadays, Putin and Snowden are no longer part of those agencies, since Putin has become a great Statesman (but retains the nominal head of such agencies) in the eyes of his countrymen, and Snowden a villain in the eyes of some of his US compatriots. However, the Snowden files confirm a new era of cybernetic cold war where internet data collection and cyberattacks is at heart.

The mass collection and storage of data in recent years also reveals another terrifying and important development that has often been overlooked; that is, the steps that have been taken by various countries towards waging a war of sorts on privacy (through data retention/data-grabbing laws), whilst at the same time enacting laws to protect privacy. ${ }^{125}$ This double-edged sword in information privacy laws is somewhat bewildering, because several countries have enacted strong data protection laws guaranteeing their citizens control and liberty over their personal and sensitive data. ${ }^{126}$ On the other hand, some of these countries have also enacted data retention laws, which allow government and their law enforcement apparatus unhindered access to the personal and sensitive data of their citizens. ${ }^{127}$ The latter approach is akin to war crimes against privacy and personal data because not only does it invade the individual liberty of the human data subject, but it also crosses borders, or attempts to cross borders, to carry out such atrocious acts. ${ }^{128}$ Furthermore, this assault on privacy is also feeding the blood line of twenty first century cybernetic warfare - leaving privacy as its main casualty. ${ }^{129}$

Nowadays an enormous amount of data are created on a daily basis by corporations, individuals, artificial intelligence devices and other entities, and most of that data is subject to the territorial laws of the State in which the data was created. That data is therefore the target of access and control by States. This data and its storage have formed a new paradigm in international relations because such data contains a wealth of information and intelligence necessary for every conceivable aspect of society to function. The data, if processed by cloud computing commercial agencies, is normally stored in server farms scattered around the world. ${ }^{130}$ Other data are stored on private server facilities,

${ }^{124}$ Anna Persky, 'Cover Blown: NSA Surveillance and Secrets' (2014) 28 Washington Lawyer 23; PD Watkins, 'FISA and NSA Spying: Are there Constitutional Implications' (2009) 2 Homeland Security Review 125; Stephanie DeVos, 'The Google-NSA Alliance: Developing Cybersecurity Policy at Internet Speed' (2010) 21 Fordham Intellectual Property Media and Entertainment Law Journal 173.

${ }^{125}$ I have discussed this at length in an article written in conjunction with this one, but which has since been published - see Morris (n 111).

${ }^{126}$ See also, Regulation 2016/679 of 27 April 2016 on the protection of natural persons with regard to the processing of personal data and on the free movement of such data, and repealing Directive 95/46/EC (General Data Protection Regulation) [2016] OJ L119/2; see also, Schullhofer (n 115) warning on the dangers of global privacy laws.

${ }^{127}$ See Morris (n 111) 32.

128 ibid.

${ }^{129}$ See also Schullhofer (n 115); Arthur Miller, The Assault on Privacy: Computers, Data Banks, and Dossiers (Ann Arbor: Michigan 1971) 2 giving perhaps one of the earliest accounts of how the early 'cybernetic age' has affected the individual's way of life and detailing the responses by the law, government and industry; Alex Kozninski and Stephanie Grace, 'The (Continued) Assault on Privacy: A Timely Book Review Forty Years in the Making' (2012) 90 Oregon Law Review 1135; Frederick Lane, American Privacy: The 400-year History of Our Most Contested Right (Beacon Press 2011); Colin Bennett and Charles Raab, The Governance of Privacy: Policy Instruments in Global Perspective (MIT Press 2006); Fred Cate, 'Government Data Mining: The Need for a Legal Framework' (2008) 43 Harvard Civil Rights-Civil Liberties Law Review 435.

${ }^{130}$ James Grimmelmann, 'The Structure of Search Engine Law' (2008) 93 Iowa Law Review 1, 10 noting that a server farm consists of many thousands of computers; Anshul Ghandi, Mor Harchol-Balter and Ivo Adan, 'Server Farms with Setup Costs' (2010) 67 Performance Evaluation 1; Albert Greenberg, James 
such as those of the SWIFT system, only to be shared with, for example, financial institutions if the data concerned is of a financial nature. ${ }^{131}$

Personal and sensitive data, and those of a simple electronic mail (or this article), are the private property of those of those that created them. Such data are then governed by the laws of the States in which they are stored. ${ }^{132}$ For example, the Russian law on data storage that came into effect on 1 September 2016 requires that all Russian citizens' personal data be stored on servers inside the Russian Federation as opposed to servers outside the Russian Federation. ${ }^{133}$ This amendment to the Russian Civil Code is technically following in the footsteps of EU law, such as the Data Protection Regulation, which requires authorisation before EU citizens' data can be transferred outside of the EU. ${ }^{134}$ Primarily, the problem that these examples highlight is the matter of access to the data; can a third State legally access it and, if so, how much of a threat to a State's national security is that? There is also the important question of whether human rights laws were breached in the process.

Accessing these kinds of data, in particular when outside the jurisdiction of the State in which they are stored, is a unique process carried out through either legal or illegal means, or through the Snowden strategy of whistleblowing when that data is considered as being trampled on by governments (what I prefer to call a war crime against privacy, due to the mass surveillance and retention of data in which various governments are engaged). For instance, in Shimovolos v Russia (2011), ${ }^{135}$ the legality of a secret surveillance security database was questioned by the ECtHR. It was found that the applicant's right to a private life under Article 8 of the European Convention on Human Rights was violated. Although this case involved the security services of Russia, States other than Russia engage in these actions. ${ }^{136}$ As some of the data that concerned the applicant emanated from his air travels, in one respect such a ruling was short of hypocrisy given that the passenger names and records (PNR) database between the US and the EU allows for similar information to be gathered on individuals. ${ }^{137}$

Particularly when the data concerned is located in another sovereign State, a State not only invades an often friendly State to carry out such heinous war crimes, but also practices a form of organised hypocrisy by ignoring the various treaties that exist for mutual assistance between States. ${ }^{138}$ Furthermore, it appears that war crimes against privacy enable States to engage in mass data surveillance as an accepted form of espionage and intelligence gathering, by targeting access to data storage facilities in overseas States.

Hamilton, David Maltz and Parveen Patel, 'The Cost of a Cloud: Research Problems in Data Center Networks' (2009) 39 Communication Review 68.

${ }^{131}$ Morris (n 111).

${ }^{132}$ For example, the recently adopted Russian law on internet data storage: see Federal Law on Personal Data and on Information, Information Technologies and Protection of Information, 4 July 2014 [0 внесении дополнения в Федеральный закон «0 введении в действие части четвертой Гражданского кодекса Российской Федерации]; N Purtova, Property Rights in Personal Data - A European Perspective (Kluwer 2011).

${ }^{133}$ Federal Law on Personal Data (n 132).

${ }^{134}$ GDPR (n 126); a recent judgment by the Court of Justice of the European Union struck down the privacy shield on the transfer of personal data outside of the EEA: see Case C-311/18 Data Protection Commissioner $v$ Facebook Ireland Limited and Maximillian Schrems [16 July 2020].

135 Shimovolos $v$ Russia App no 30194/09 (ECtHR, 21 June 2011).

${ }^{136}$ See, for example, Pretty $v$ United Kingdom App no 2346/02 (ECtHR, 29 April 2002).

${ }^{137}$ See Agreement between the United States and the EU on the Use and Transfer of Passenger Name Records to the United States Department of Homeland Security (11 August 2012) OJ L 215/5.

${ }^{138}$ See Morris (n 111) 32. 


\section{Human Rights as a Problem: Some Doctrinal Perspectives}

The general academic debate and contribution to the analysis of human rights in international law is such a great body of work that the science of human rights itself has hardly any room for criticism. Yet, this modern science of human rights has also a problem that is crucial for its survival. The language, practice and rhetoric of human rights are a problem because they have traversed many disciplines and such adaption has resulted in different interpretation and practice.

The modern conception of human rights is a product of post-war normative instruments such as the UDHR, which stipulates in Article 1 that 'all human beings are born free and equal in dignity and rights' ${ }^{139}$ This not only set the legal tone for (international) human rights law but also created a new science of human rights where practitioners are vastly shielded from reality. It is this science, which is also part of the problem and is in search of meaning and original intent outside of exotic field trips.

In the rest of this paper, I will highlight in broader context what I see as some of the problems with the science of human rights that are generally lacking in the literature and how human rights practitioners perceive it. My analysis of these points is not to argue that the human rights literature in general should develop these arguments. I want to merely offer a critique of what I see as some of the problems with the practice and rhetoric of human rights.

\section{i. 'Historicities' and clashes of regimes involving human rights}

Much of the historicities of human rights were not necessarily attributed to human rights as we understand them today. The historical origins of human rights were concerned with religion, ethics or the morally right thing to do when the dignity of fellow humans was being degraded, deprived or robbed in inhumane or atrocious ways. ${ }^{140}$ Saving the life of a fellow believer during the Inquisition or helping to free a plantation slave was not necessarily motivated by human rights; it was motivated by the religious ethics of the few good men of the times. ${ }^{141}$ The massacres of thousands of Chinese citizens in the nineteenth and twentieth centuries were grave crimes, ${ }^{142}$ as were the killings of thousands of Christians in Syria and Lebanon in the nineteenth century. ${ }^{143}$ In contemporary times, the trend still exists, where massacres and other forms of genocide occur in modern conflicts. These developments should not be seen as a human rights problem perse. Rather, such crimes are in themselves serious crimes, and local and international legal norms can respond adequately to them without invoking the language of human rights. Invoking human rights when considering the severity of such crimes unnecessarily convolutes and obstructs the proper application of the relevant legal instruments.

This also raises a deeper question: that of where to draw the line between applicable laws, such as criminal law, and human rights. Should all such crimes and atrocities be

${ }^{139}$ UDHR (n 49) Article 1.

${ }^{140}$ See, for example, Rik Torfs, 'Human Rights in the History of the Roman Catholic Church' in HansGeorg Ziebertz and Johannes van der Ven (eds), Human Rights and the Impact of Religion (Brill 2013) 5574.

${ }^{141}$ See also Ralph Mclnerny, 'Natural Law and Human Rights' (1991) 36 American Journal of Jurisprudence 1; RP Boast, 'The Spanish Origins of International Human Rights Law: A Historiographical Review' (2010) 41 Victoria University of Wellington Law Review 235.

${ }^{142}$ See, for example, Burensain Borjigin, 'The Complex Structure of Ethnic Conflict in the Frontier: Through the Debates around the Jindandao Incident in 1891' (2004) 6 Inner Asia 41.

${ }^{143}$ Eugene Rogan, 'Sectarianism and Social Conflict in Damascus: The 1860 Events Reconsidered' (2004) 51 Arabica 493. 
grouped under crimes against humanity, where they are broadly a violation of the laws of war, human rights conventions and local criminal laws? Or more provocatively, to give legitimacy to human rights norms and principles nationally and internationally, should such crimes also include charges of human rights violations? This is only one area where human rights pose a problem, as what is largely conceived as human rights clashes with various legal regimes.

These clashes of legal regimes go deeper, to the legal origin of human rights in the modern and international context, and to how that origin relates to domestic rights that were found in various State constitutions prior to the emergence of instruments such as the UDHR and other international legal instruments that are modeled thereon. The clash of legal regimes in the human rights movement is only the tip of the iceberg and it is up to legal scholars to go beyond the mere interpretation of current human rights instruments to offer a concerted and methodological normative discourse, in order to derail clashes of legal regimes involving human rights.

\section{ii. Interdisciplinary studies}

Scholarly output often benefits from the critique or the knowledge of experts in other fields and this often generates an interdisciplinary approach. In the field of human rights, interdisciplinary studies are voluminous and the literature keeps growing.

The problem with the interdisciplinary approach to human rights is that not only are too many hands painting the same fence, but the paint can be corrosive and the fence may gradually decay. This is the major problem facing the language, practice and rhetoric of human rights. In addition to this corrosive paint, other scientific fields that are on the verge of extinction or face academic glut jump on the human rights bandwagon and freeride their way to prominence. ${ }^{144}$ This leaves the target, the human, out of human rights and relegates it to a largely academic rhetorical discourse.

Nowhere in this grand game of rhetoric is the human present, nor is his dignity a practical concern. ${ }^{145}$ The rhetoric of human rights through an interdisciplinary approach is not only a cottage industry in most Western nations, but also creates a false sense of security in the rest of the world and in the efforts of people to survive the practicalities of everyday live or the perceived injustices created by (international) legal instruments in the Western world. ${ }^{146}$

While there are added benefits of interdisciplinary approaches to human rights, the science itself has created a division among various academics and this division is borne out through interdisciplinary interpretation while, at the same time, human rights allows for the propping up of failed academic disciplines. ${ }^{147}$ Similar to grey clouds that can be shifted by the wind, human rights as a language and tool of rhetoric, often used by the Western world, are expanding due to interdisciplinary approaches. Such grey clouds darken the

\footnotetext{
${ }^{144}$ When this article was first written, I had specific fields in mind, but my memory lags upon revision several years later to pinpoint a specific field. Needless to say, there are indeed interdisciplinary challenges with human rights; see, for example, Lindsey Kingston, 'The Rise of Human Rights Education: Opportunities, Challenges, and Future Possibilities' (2014) 9 Societies Without Borders 188.

${ }^{145}$ See, however, Christopher McCrudden, 'Human Dignity and Judicial Interpretation of Human Rights' (2008) 19 EJIL 655.

${ }^{146}$ Some of the more scientific forms of this claim can also be inferred, see Sally Merry, 'Global Human Rights and Local Social Movements in a Legally Plural World' (1997) 12 Canadian Journal of Law and Society 247.

${ }^{147}$ See my comment above (n 144); for some critical reflections see Sara O'Neill, 'The Dark Side of Human Rights' (2005) 81 International Affairs 427.
} 
original purpose of human rights, and human rights becomes a problem as it has come to a crossroads without any sense of direction.

\section{iii. What does it really mean to have human rights?}

Does a country's (conservative) values and opposition to same-sex marriage really involve human rights? Another problematic area in the human rights movement is the real meaning of human rights. Human rights can be attributed to anything and this creates a false sense of security regarding the real meaning of human rights. If a country enacts laws in order to ensure that the family is not diluted by ensuring that fathers have an equal say in parenting, does it really discriminate against same sex-couples and, if so, is that a human rights problem? In a sense yes, based on the current trend in human rights courts (mostly in the Western world), it is a human rights problem.

We have seen this in Vallianatos and Others $v$ Greece, ${ }^{148}$ and other cases where a human rights claim can offer judicial reprieve for those who felt disadvantaged by laws or State actions. Same-sex issues are not the only ones that human rights have solved. Violent criminals, sex offenders, asylum seekers and immigrants alike have used the courts (again, mostly in the Western world) to argue that their human rights have been violated. ${ }^{149}$

What is interesting about these claims is that they are often made by those originally from other parts of the world, where Western standards of human rights are not fully practiced per se. For instance, in $J R v$ Secretary of State $(U K),{ }^{150}$ a Caribbean man was ordered to be deported from the UK after he served a prison sentence for the killing of another man. However, the English Court of Appeal held that the man could not be deported as it would violate his human rights under Article 3 of the Human Rights Act (UK), ${ }^{151}$ since the man in question asserted at the last minute that he was gay.

Furthermore, in other instances, such as in Kiobel $v$ Shell, ${ }^{152}$ citizens of States where Western standards of human rights are questionable often resort to human rights to seek financial compensation, by alleging that their human rights have been violated by a corporate entity for aiding and abetting alleged atrocities. The larger point here is that human rights have become a farce whereby they are applicable to all things, yet the courts must often comply with legislation that is being abused. Such abuse is largely the making of the Western world as it broadly adopted the language of human rights and enacted legislation reflecting that language in order to give an image of civility beyond their borders.

Given the numerous atrocities that the majority of countries in the Western world have allegedly committed in the last five centuries, either by wars or colonisation, ${ }^{153}$ it sometimes seems that the language of human rights and its accompanying laws are a way of expressing guilt and apology. The question of what human rights really means goes beyond the vernacular from European to 'global South' languages. It is also akin to a large

148 Case of Valliantos and Others $v$ Greece App Nos 29381/09 and 32684/09 (ECtHR, 7 November 2013).

${ }^{149}$ A classic example is raising human rights claims when objecting to deportation; see also Vanessa Bettinson, 'Deportation of Migrant Following Criminal Conviction: European Convention on Human Rights, Article 8' (2010) 74 Journal of Criminal Law 113; See also R (On the application of JR (Jamaica) $v$ Secretary of State for the Home Department, EWCA Civ 477 (2014).

${ }^{150} R$ (On the application of JR (Jamaica) v Secretary of State for the Home Department, EWCA Civ 477 (2014).

151 Human Rights Act (1998) (UK), Article 3.

152 Kiobel v Royal Dutch Petroleum Co., 133 S Ct 1659 (2013).

153 See for example, Patrick Wolfe, 'Settler Colonialism and the Elimination of the Native' (2006) 8 Journal of Genocide Research 387; for discussion on early twentieth century genocide in a colonial context see Rachel Anderson, 'Redressing Colonial Genocide under International Law; The Hero's' Cause of Action Against Germany' (2005) 93 California Law Review 1155. 
patch of sky, covered with grey clouds that can be easily moved by winds to another part of the sky. In this constant shift of grey clouds, anyone and anything can argue that it rained on them and thus violated their human rights.

The above perspectives are some singular insights into the direction of international human rights rhetoric in the global sphere and how that rhetoric can easily be adapted to suit other norms such as national security.

\section{Conclusion}

From the above analysis, one thing that does seem to have emerged is that international human rights law does not offer protection to domestic situations regarding the violation of human rights. In other words, where national security intersects with human rights violations at the domestic level, international human rights law is weak because there are so many firewalls against what is considered national security at the domestic level, which States can invoke based on their domestic laws.

Within the realm of international relations and international law operations, it is up to States to determine the reach and scope of international law and, as such, 'the nation State still prevails globally, international law is not normally legally binding domestically unless it is incorporated into national legislation. ${ }^{154}$ Furthermore, where international law is incorporated into domestic legislation, the risk of incompatibility with other constitutional norms may render international human rights norms incompatible with national security legislation.

Naturally, the views in this paper are only some of many questions that those who sit on the opposing side can raise regarding human rights. The more questions asked, the more academics in various fields struggle to come up with the right answers that can satisfy the curious questioner. On the one hand, some academics tend to gather radical minds to think freely and present their conception of human rights and, on the other, some academics offer their insights from years of practice in human rights settings. What most of us can agree is that human rights are a force to be reckoned with and have probably come to a crossroads.

\section{grojil.org}

${ }^{154}$ Head and Mann (n 6) 177. 